\title{
Monitoring and Modeling the Patterns and Trends of Urban Growth Using Urban Sprawl Matrix and CA-Markov Model: A Case Study of Karachi, Pakistan
}

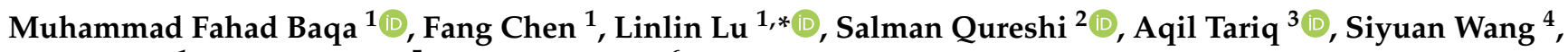 \\ Linhai Jing ${ }^{1}$, Salma Hamza ${ }^{5}$ and Qingting $\mathrm{Li}^{6}$ \\ 1 Key Laboratory of Digital Earth Science, Aerospace Information Research Institute, \\ Chinese Academy of Sciences, Beijing 100094, China; 2252293808@mails.ucas.edu.cn (M.F.B.) \\ chenfang@radi.ac.cn (F.C.); jinglh@aircas.ac.cn (L.J.) \\ 2 Institute of Geography, Humboldt University of Berlin, 12489 Berlin, Germany; \\ salman.qureshi@geo.hu-berlin.de \\ 3 State Key Laboratory of Information Engineering in Surveying, Mapping and Remote Sensing (LIESMARS), \\ Wuhan University, Wuhan 430079, China; aqiltariq@whu.edu.cn \\ 4 Research Center for Eco-Environmental Sciences, State Key Laboratory of Urban and Regional Ecology, \\ Chinese Academy of Sciences, Beijing 100085, China; wangsy@rcees.ac.cn \\ 5 Department of Earth and Environmental Sciences, Bahria University Karachi Campus, \\ Karachi 75300, Pakistan; salma.bukc@bahria.edu.pk \\ 6 Airborne Remote Sensing Center, Aerospace Information Research Institute, Chinese Academy of Sciences, \\ Beijing 100094, China; liqt@radi.ac.cn \\ check for \\ updates \\ * Correspondence: lull@radi.ac.cn
}

Citation: Baqa, M.F.; Chen, F.; Lu, L.; Qureshi, S.; Tariq, A.; Wang, S.; Jing, L.; Hamza, S.; Li, Q. Monitoring and Modeling the Patterns and Trends of Urban Growth Using Urban Sprawl Matrix and CA-Markov Model: A Case Study of Karachi, Pakistan. Land 2021, 10, 700. https://doi.org/ 10.3390/land 10070700

Academic Editors: Luca Salvati, Iwona Cieślak and Andrzej Biłozor

Received: 17 June 2021

Accepted: 1 July 2021

Published: 2 July 2021

Publisher's Note: MDPI stays neutral with regard to jurisdictional claims in published maps and institutional affiliations.

Copyright: (c) 2021 by the authors. Licensee MDPI, Basel, Switzerland. This article is an open access article distributed under the terms and conditions of the Creative Commons Attribution (CC BY) license (https:// creativecommons.org/licenses/by/ $4.0 /)$

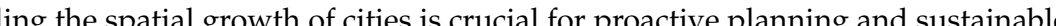
urbanization. The largest and most densely inhabited megapolis of Pakistan, Karachi, has experienced massive spatial growth not only in the core areas of the city, but also in the city's suburbs and outskirts over the past decades. In this study, the land use/land cover (LULC) in Karachi was classified using Landsat data and the random forest algorithm from the Google Earth Engine cloud platform for the years 1990, 2000, 2010, and 2020. Land use/land cover classification maps as well as an urban sprawl matrix technique were used to analyze the geographical patterns and trends of urban sprawl Six urban classes, namely, the primary urban core, secondary urban core, sub-urban fringe, scatter settlement, urban open space, and non-urban area, were determined for the exploration of urban landscape changes. Future scenarios of LULC for 2030 were predicted using a CA-Markov model. The study found that the built-up area had expanded in a considerably unpredictable manner, primarily at the expense of agricultural land. The increase in mangroves and grassland and shrub land proved the effectiveness of afforestation programs in improving vegetation coverage in the study area. The investigation of urban landscape alteration revealed that the primary urban core expanded from the core districts, namely, the Central, South, and East districts, and a new urban secondary core emerged in Malir in 2020. The CA-Markov model showed that the total urban built-up area could potentially increase from $584.78 \mathrm{~km}^{2}$ in 2020 to $652.59 \mathrm{~km}^{2}$ in 2030. The integrated method combining remote sensing, GIS, and an urban sprawl matrix has proven invaluable for the investigation of urban sprawl in a rapidly growing city.

Keywords: urban sprawl; Landsat; CA-Markov model; SDG 11; urban sustainable development

\section{Introduction}

Urbanization is a complex socioeconomic process that shifts the distribution of a population from dispersed rural settlements to dense urban settlements [1]. In spatial terms, the urbanization process is manifested in the physical development of urban settlements and the transition of landscapes into urban forms [2,3]. In the Global South, rapid and unplanned urban sprawl leads to problems such as fragmented landscape, reduction in arable 
land, increase in urban poverty, and environmental degradation, which pose a huge threat to sustainable development in these regions [4-6]. By 2030, Sustainable Development Goal 11 of the United Nations intends to make cities and human settlements more inclusive, safe, resilient, and sustainable [7]. Building policies to promote the sustainable development of cities, especially in developing countries, need accurate and timely monitoring and understanding of the spatial growth of urban settlements [8].

Geospatial techniques have enabled the analysis and forecasting of urban growth at regional and global scales. These methods are useful for observing and understanding the dynamics of urban landscapes $[6,9,10]$. Previously, efforts have been made to model and analyze urban spatial growth and patterns using methods such as cellular automata [11-13], the artificial neural network [14,15], the Markov chain [16,17], geographical weighted regression [18], the non-ordinal and Sleuth model [19-21], the analytic hierarchy process [22], machine learning models [23,24], and an urban sprawl matrix [25,26]. Batty demonstrated how cellular and agent-based models have the ability to clearly incorporate spatial interaction and mobility [27]. Considering the limitation of basic logistic regression models, Arsanjani et al. used a hybrid model to uncover the interaction of various environmental and socioeconomic variables that cause urban expansion [28]. By combining the CA model's benefit of modeling spatial variation in complex systems with the Markov model's advantage of long-term prediction, the CA-Markov model was developed, which is an effective method for simulating LULC transformation. It has been widely applied to examining and measuring urbanization and landscape dynamics [29]. The Markov model predicts the future status of a land use based on its current rate [30]. Cellular automata (CA) detects the geographic location of changes, whereas the Markov chain predicts future change based on the past [30].

Karachi, Pakistan's largest city, has seen massive urban growth in recent decades not only in the city's center, but also in the surrounding suburbs [6]. If the urban land expansion rate is higher than the population increase rate, the population density in the urban area will significantly decline, and the phenomena of urban sprawl will occur. Due to institutional inefficiency and governance failure, rural lands have been converted into residential and industrial areas without considering the urban planning schemes in Karachi [31]. The massive conversion of rural lands for urban areas has caused the sprawl phenomenon since 2000, which has led to loss of agricultural lands, an increase in commuting costs, and flooding [31]. The unplanned urban sprawl has also resulted in a range of social problems such as a lack of health care, shortage of education facilities and infrastructures, an increase in criminal incidents, and sociocultural imbalance [32-34]. The introduction of new urban forms and structures that adapt to climate change issues can mitigate the environmental problems caused by dispersed urban area growth and create more efficient urban economies [35]. Therefore, the spatiotemporal modeling of urban sprawl is crucial to better understand the changing urban patterns of Karachi divisions, thus helping local governments in prioritizing the demands of the local population and formulating strategies and practical solutions to achieve the goal of urban sustainable development.

Previous studies have attempted to use remote sensing data to analyze the general pattern of urban land cover changes and urban suitability in Karachi $[36,37]$. Although land use land cover changes were significant based on the analysis using satellite imagery, the landscape changes during the urbanization process were not fully investigated. Moreover, the simulation and prediction of future LULC scenarios in the growing city have barely been reported. To fill such gaps, this study aimed to thoroughly analyze the LULC changes and the spatiotemporal dynamics of urban expansion in Karachi using satellite data from 1990 to 2020. The future LULC scenarios and urban expansion were also simulated using a CA-Markov model in the city for the year 2030. 


\section{Study Area and Datasets}

\subsection{Study Area}

Karachi, the provincial capital of Sindh, is Pakistan's largest and most densely populated megacity. It is the principal industrial center, seaport, and financial and commercial hub. Karachi Urban Agglomeration (Karachi UA), extending over $3527 \mathrm{~km}^{2}$, is located on the coastline of the Arabian Sea, between $24^{\circ} 45^{\prime} \mathrm{N}$ to $25^{\circ} 15^{\prime} \mathrm{N}$ and $66^{\circ} 37^{\prime} \mathrm{E}$ to $67^{\circ} 37^{\prime} \mathrm{E}$ (Figure 1). Karachi is mainly made up of flat rolling plains with hills on the western and northern boundaries. The southern and southeastern banks of the Malir River have a contagious linear concentration of urban settlements [38].

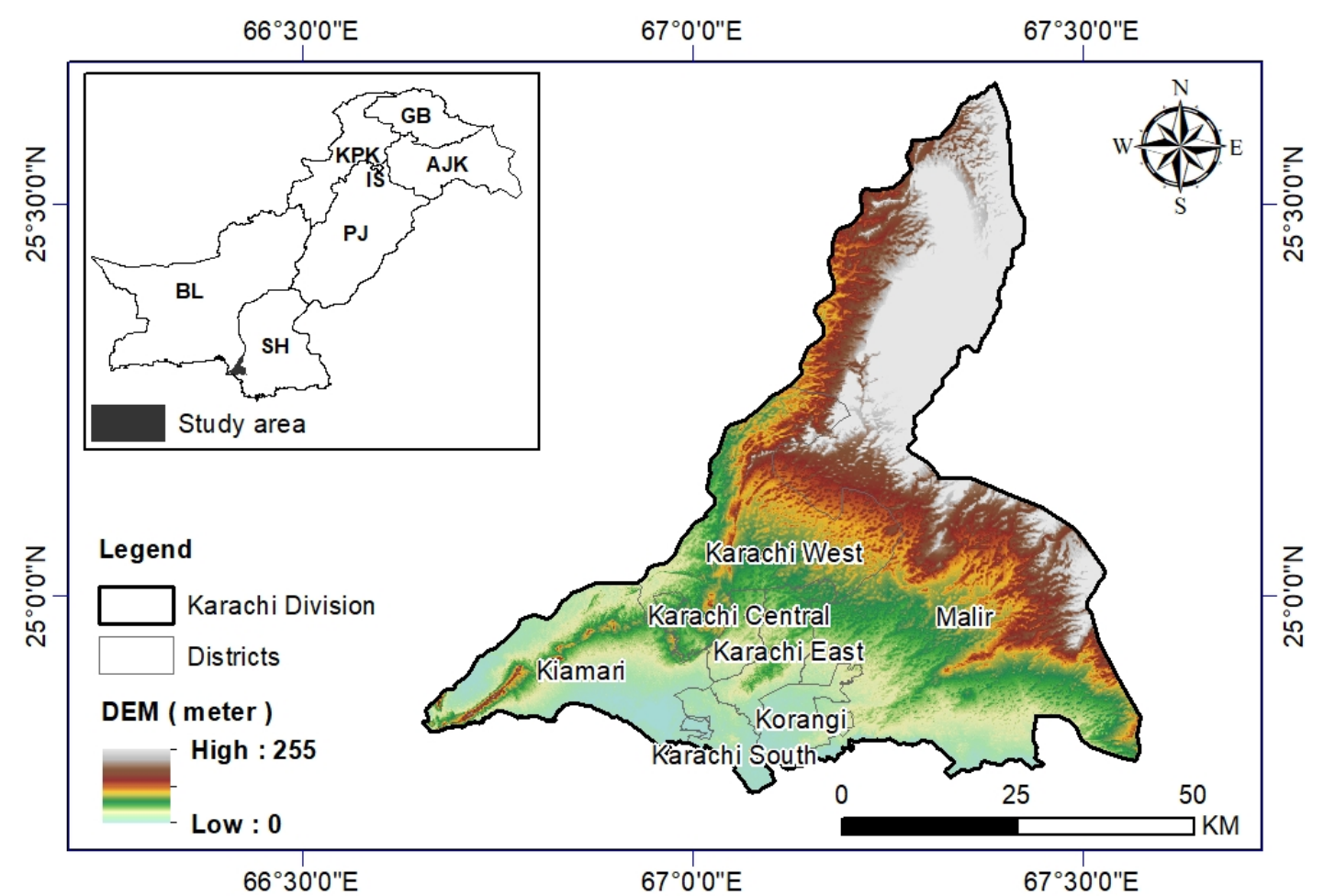

Figure 1. Study area. $\mathrm{PJ}=$ Punjab; $\mathrm{SH}=\mathrm{Sindh} ; \mathrm{BL}=$ Balochistan; $\mathrm{IS}=$ Islamabad; $\mathrm{AJK}=$ Azad Jammu Kashmir; GB = Gilgit-Baltistan; KPK = Khyber Pakhtunkhwa.

According to the 2017 Census Report [39], more than 16 million people live in Karachi, and the population will increase to more than 20 million by 2025 with a density of 4115 persons per square kilometer [40,41]. The city consists of seven districts, which can be further divided into 31 sub-divisions [39]. As an increasing metropolitan city in a developing country, Karachi faces unplanned urban expansion, inappropriate essential infrastructure and facilities, crises in drinking water and solid-waste management services, inconvenient public transport, environmental pollution, and poor governance [42]. Of the total population, nearly $40 \%$ live in slum areas $[43,44]$.

\subsection{Datasets}

The primary data source for measuring urban spatial patterns and analyzing the trend of urban growth in Karachi was Landsat Thematic Mapper (TM) pictures from 1990, 2000, and 2010 as well as Landsat 8 OLI images from 2020 from Google Earth Engine (Table 1). The atmospheric correction technique LaSRC was used to correct the available Landsat Surface Reflectance Tier 1 data in Google Earth Engine. The CFMASK algorithm was used to mask cloud, shadow, and water regions in these images. The entire study area covered three Landsat tiles (152_042, 152_043, and 153_043). The atmospherically corrected and cloud removed images with a ten-year interval were used to perform the initial LULC classification. As supplementary features for land cover classification, the 
normalized difference vegetation index (NDVI) and the normalized built up index (NDBI) were computed for each decadal image [45].

Table 1. Details of datasets used in this study.

\begin{tabular}{cccc}
\hline Data & Details & Period & Source \\
\hline Landsat images & 30 m resolution, Path/Row 152,042, 152/043, 153/043 & $1990-2020$ & USGS \\
Base map & scale 1:25,000 & 2000 & SOP \\
Population & divisional level & $1990-2020$ & COP \\
DEM & SRTM DEM and Slope & 2015 & USGS \\
Roads & Road Network & 2018 & OSM \\
\hline
\end{tabular}

Several datasets were used as supplementary data in our study (Table 1). To distinguish LULC classes between plain and hilly areas, SRTM digital elevation model (DEM) data were employed. To evaluate the accuracy of LULC, high spatial resolution images with multiple acquisition dates collected from Google Earth and topographical maps published by the Survey of Pakistan, Government of Pakistan were used as reference data. District-level population data were gathered for the years 1990, 2000, 2010, and 2020 from the official census and Pakistan Bureau of Statistics [39]. The road network data were used to train the CA-Markov model for the LULC scenario simulation.

\section{Methods}

The workflow was primarily comprised of three steps: classification of land use/land cover, analysis of urban expansion, and modeling of future LULC scenarios. Figure 2 depicts the entire data processing workflow adopted in this study.

\subsection{Land Use/Land Cover Classification}

We used the Google Earth Engine's random forest classification technique to produce land use/land cover maps for the years 1990, 2000, 2010, and 2020 in the study area [46]. The overall accuracy (OA), producers' accuracy (PA), and users' accuracy of the classification results were measured using the confusion matrix [46].

\subsection{Urban Landscape Change Analysis}

The post-classification change matrix methodology was used to create a land use/land cover change map from 1990 to 2020. To analyze land use/land cover changes, a transition model was developed using cross-tabulation in the GIS module. The transition matrix indicates that the study area had experienced major alterations.

An urban sprawl matrix was utilized to examine urban expansion dynamics and measure urban spatial patterns in Karachi [47]. For the categorization of urban spatial patterns, matrix functions based on urban pixels were used. Using the urban sprawl matrix, the study area was divided into six classes, namely, the urban primary core, urban secondary core, suburban fringe, scatter settlement, urban open space, and non-urban area (Table 2 and Figure 3). 


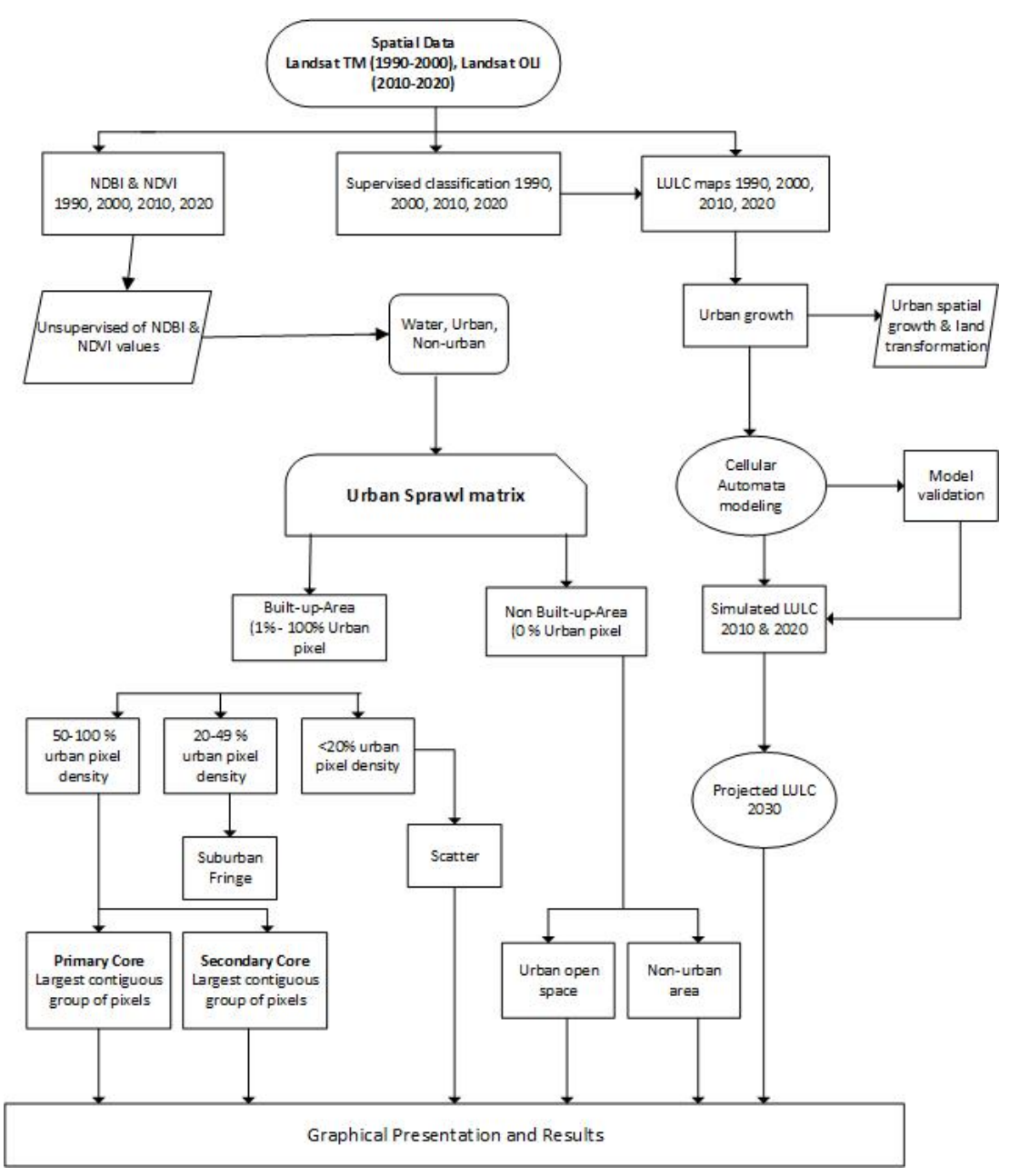

Figure 2. The data processing workflow in this study.

Table 2. Classification of the study area into urban spatial patterns.

\begin{tabular}{|c|c|}
\hline Urban Spatial Patterns & Criteria \\
\hline Urban primary core & $\begin{array}{l}\text { The most densely packed set of pixels in which at least } 50 \% \text { of } \\
\text { the surrounding neighborhood is densely populated. }\end{array}$ \\
\hline Urban secondary core & $\begin{array}{c}\text { It is at least } 50 \% \text { built-up in the same way as urban primary } \\
\text { core although it is not part of it. }\end{array}$ \\
\hline Suburban fringe & $\begin{array}{l}\text { The built-up pixels with a } 30-50 \% \text { urbanness surrounded by } \\
\text { primary and secondary core. }\end{array}$ \\
\hline Scatter settlement & $\begin{array}{l}\text { The built-up pixel is less than } 20 \% \text { built up and is located } \\
\text { apart from the primary and secondary cores. }\end{array}$ \\
\hline Urban open space & $\begin{array}{l}\text { The non-urban regions encircled the primary and secondary } \\
\text { urban cores. }\end{array}$ \\
\hline Non-urban area & $\begin{array}{l}\text { Apart from the primary and secondary urban cores, } \\
\text { non-urban area. }\end{array}$ \\
\hline
\end{tabular}




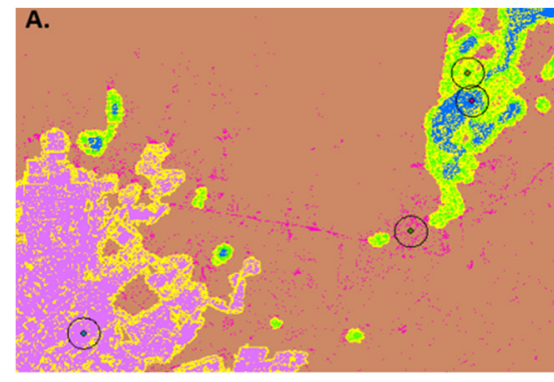

A. Sample location of urban spatial for urban sprawl index

1. Matrix function of urban primary core

Matrix function of urban secondary core

Matrix function of suburban fringe

4. Matrix function of scatter settlement

Urbanness for each pixel is percent of built-up area in a circle of radius $1 \mathrm{KM}$ area centered on the pixel under consideration.
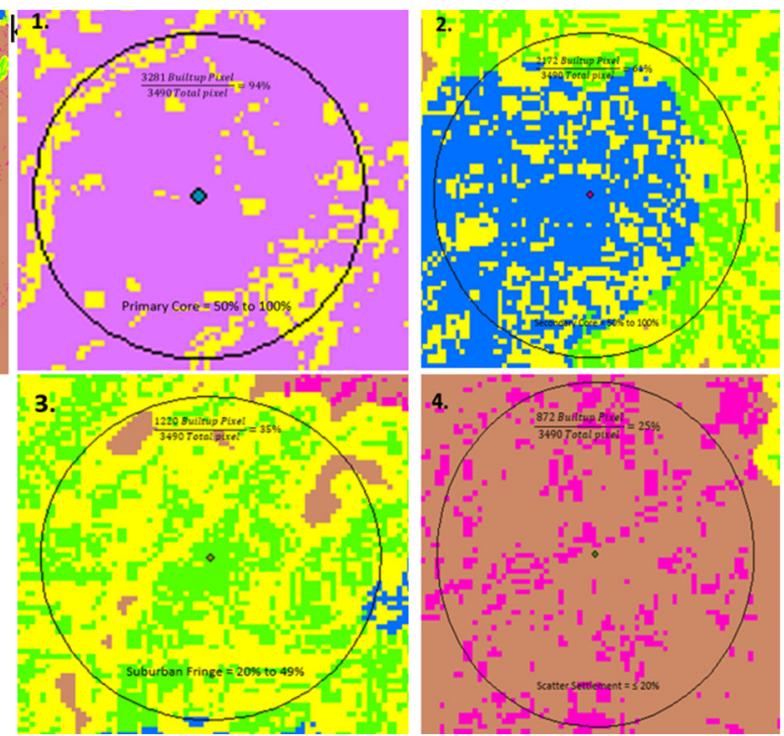

Figure 3. Depiction of the function of the urban sprawl matrix and urban spatial pattern. The percentage of the built-up area in a $1000 \mathrm{~m}$ radius circle centered on the pixel under examination is the pixel's urbanness.

\subsection{LULC Simulation}

CA-Markov simulation was implemented using several steps: (a) the generation of LULC maps with the same time interval (1990, 2000, 2010, and 2020); (b) the calculation of transition probability matrices based on LULC maps; (c) the generation of transition suitability maps using driving factors such as distance to water body, distance to main roads, distance to built-up areas, and slope [4,31]; (d) the evaluation of the model's ability to simulate future changes using a kappa index of agreement (KIA) approach; and (e) the simulation of LULC maps for the predicted year (here, 2030). The projections of LULC change in the study area were performed using the land change modeler (LCM) within the TerrSet software (Clarke Labs 2019, https: / / clarklabs.org (accessed on 10 December 2020) [48].

As an input to the CA-Markov model, the Markov chain model was employed to produce a transition probability matrix between an initial state and a final state. The transitional probability matrices were generated using LULC information from 2010 to 2020 in order to investigate how each land cover class was expected to change. The Markov model can be described using the following equation:

$$
\mathrm{S}(\mathrm{t}+1)=P_{i j} \times \mathrm{S}(\mathrm{t})
$$

where $S$ represents the land use condition at time $t ; S(t+1)$ represents the land use status at time $\mathrm{t}+1$; and $P_{i j}$ is the transition probability matrix in a certain state, which is calculated using the following equations [49]:

$$
\begin{gathered}
\left\|P_{i j}\right\|=\left\|\begin{array}{ccc}
P_{1,1} & P_{1,2} & P_{1, N} \\
P_{2,1} & P_{2,2} & P_{2, N} \\
P_{N, 1} & P_{N, 2} & P_{N, N}
\end{array}\right\| \\
\left(0 \leq P_{i j} \leq 1\right)
\end{gathered}
$$

where $P$ refers to the transition probability; $P_{i j}$ refers to the probability of changing from state $i$ to state $j$ in the next time; and PN refers to the state probability of any time. The low transition probability is close to 0 , and the high transition probabilities is close to 1 [49].

Using the multi-criteria evaluation (MCE) module, suitability maps, which show the suitability of cell transformation for a particular land cover type, were created for the application of the CA model. The characteristics of LULC types were taken into considera- 
tion. For example, the built-up area cannot be converted into a water body [50,51]. As an inherent part for geospatial modeling, the kappa index of agreement (KIA) representing the model's simulation accuracy was used here to evaluate the model's ability to simulate the spatial pattern of land use [52,53]. The KIA was calculated with the following equation:

$$
\mathrm{KIA}=\operatorname{Pr}(\mathrm{a})-\operatorname{Pr}(\mathrm{e}) / 1-\operatorname{Pr}(\mathrm{e})
$$

where $\operatorname{Pr}(\mathrm{a})$ refers to the observed agreement, and $\operatorname{Pr}(\mathrm{e})$ refers to chance agreement. The kappa coefficients (K-no, K location, and K-standard as well as the overall kappa coefficient) were used to compare the simulated and the LULC map based on remote sensing data of 2020. The kappa coefficient values were calculated using TerrSet IDRISI software.

\section{Results and Discussion}

\subsection{LULC Change}

In the study area, six LULC classes were identified: bare land, built-up area, cultivated land, grassland and shrub land, water body, and mangroves (Figure 4). According to the accuracy assessment results, the overall classification accuracies were $89,91,91$, and $89 \%$ for 1990, 2000, 2010, and 2020, respectively. The kappa coefficient values were $0.86,0.90$, 0.89 , and 0.87 for $1990,2000,2010$, and 2020, respectively.
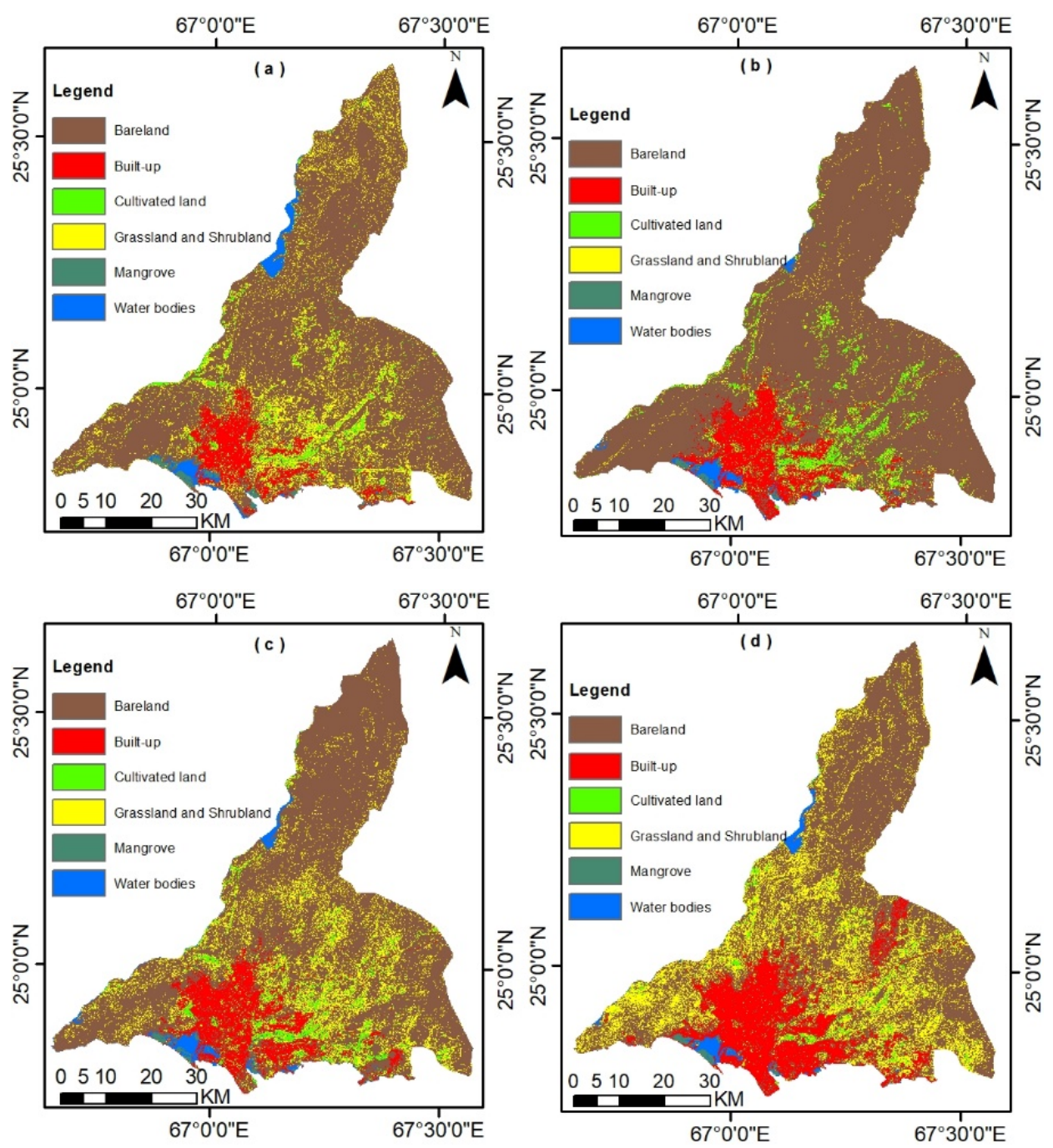

Figure 4. LULC map of Karachi in (a) 1990, (b) 2000, (c) 2010, and (d) 2020. 
Over the last three decades, the land use/land cover in the study region has changed dramatically (Table 3). Between 1990 and 2020, the area covered by built-up area and grassland and shrub land expanded, while the area occupied by agricultural land, mangroves, and open bare ground declined. Divergent changing trends were revealed in the time periods before 2000 and after 2000 for cultivated land, grassland, and shrub land, and mangroves (Table 3). The increase in the area of mangroves and grassland and shrub land since 2000 indicates that afforestation programs have played a positive role in improving vegetation coverage in the study area. The Sindh Forest Department made great efforts to restore and plant endangered mangrove species. With the help of local communities, they planted more than 800,000 saplings of Rhizophora mucronata mangroves in the coastal zone of Pakistan in 2013 [54]. The decrease in cultivated land was observed near the built-up area, which indicates urban expansion at the cost of cultivated land (Figure 4).

Table 3. Areal changes in each land use land cover type in Karachi.

\begin{tabular}{cccccccc}
\hline \multirow{2}{*}{ LULC Classes } & \multicolumn{4}{c}{ Area (sq.km) } & \multicolumn{3}{c}{ Change Rate (\%) } \\
\cline { 2 - 8 } & $\mathbf{1 9 9 0}$ & $\mathbf{2 0 0 0}$ & $\mathbf{2 0 1 0}$ & $\mathbf{2 0 2 0}$ & $\mathbf{1 9 9 0 - 2 0 0 0}$ & $\mathbf{2 0 0 0 - 2 0 1 0}$ & $\mathbf{2 0 1 0 - 2 0 2 0}$ \\
\hline Bare land & 2663.7 & 2811 & 2491.7 & 2156.6 & 5.53 & -11.35 & -13.44 \\
Built-up area & 221.1 & 358.7 & 424.3 & 573.9 & 62.23 & 18.28 & 35.25 \\
Cultivated land & 112.2 & 159.3 & 148.4 & 81.5 & 41.97 & -6.84 & -45.08 \\
Grassland and shrub land & 534.3 & 370.5 & 563 & 867.7 & -30.65 & 51.95 & 54.12 \\
Mangroves & 65.9 & 13.8 & 14.2 & 17 & -79.05 & 2.89 & 19.71 \\
Water bodies & 23.8 & 46.5 & 54 & 56.8 & 95.37 & 16.12 & 5.18 \\
\hline
\end{tabular}

The increase in urban areas in different districts of the study area is illustrated in Figure 5. It was observed that districts near coast and far from the core area (Karachi Central, South, and East districts) had a record high urban growth from 1990 to 2020, particularly in the Malir (417.92\%), West (279.38\%), and Kiamari (257.05\%) districts (Table 4). Among the core areas, the East district of Karachi experienced a higher increase in the built-up area than that in the Central and South districts of Karachi. The central city's congestion caused outgrowth at the periphery of the megacity during the study period. As a main driver of built-up area growth, the density of the population in Karachi has constantly been increasing over the last three decades. The population of central city has remained highly concentrated, and its population increased from 1.8 million in 1990 to 3.09 million in 2020. Simultaneously, the population of the suburban Malir and West districts increased from 0.8 million and 0.7 million in 1990 to 2.8 million and 2.23 million in 2020, respectively [39]. 


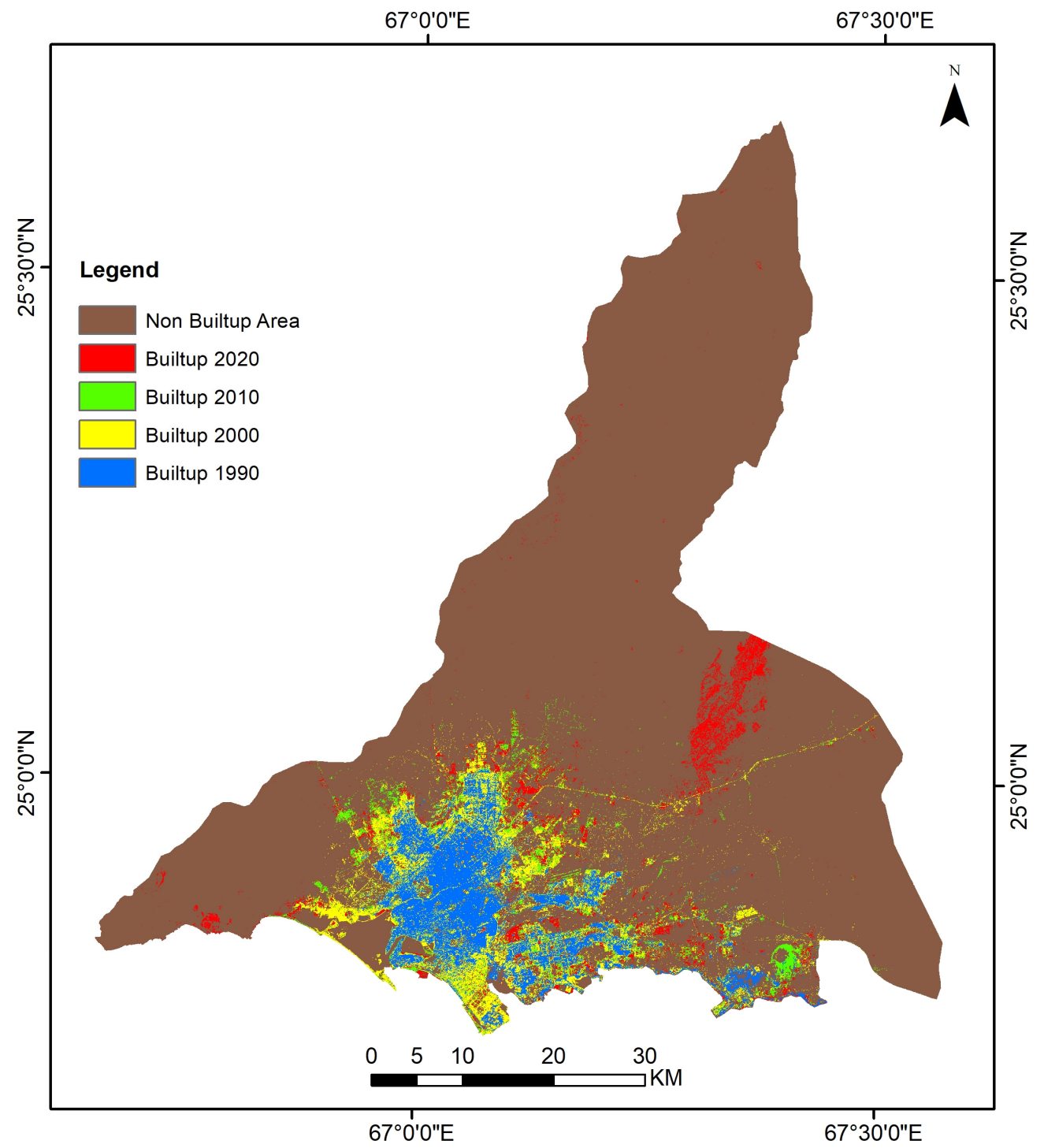

Figure 5. Built-up area expansion in Karachi in 1990, 2000, 2010, and 2020.

Table 4. Built-up area increases in each district of Karachi (in percentage).

\begin{tabular}{ccccc}
\hline District & $\mathbf{1 9 9 0 - 2 0 0 0}$ & $\mathbf{2 0 0 0 - 2 0 1 0}$ & $\mathbf{2 0 1 0 - 2 0 2 0}$ & $\mathbf{1 9 9 0 - 2 0 2 0}$ \\
\hline Kiamari & 118.49 & 3.08 & 14.13 & 257.05 \\
Central & 29.67 & -3.95 & 3.11 & 128.43 \\
South & 29.07 & -0.77 & 11.64 & 142.97 \\
West & 96.63 & 26.78 & 12.07 & 279.38 \\
East & 47.61 & 3.95 & 22.57 & 188.07 \\
Korangi & 29.91 & 10.75 & 28.98 & 185.59 \\
Malir & 66.16 & 19.13 & 111.12 & 417.92 \\
\hline
\end{tabular}

Figure 6 shows the land transformation in various districts and time periods induced by the process of urbanization. The majority of areas converted to urban land at the expense of open bare land, grassland and shrub land, and agricultural land (Table 5). 


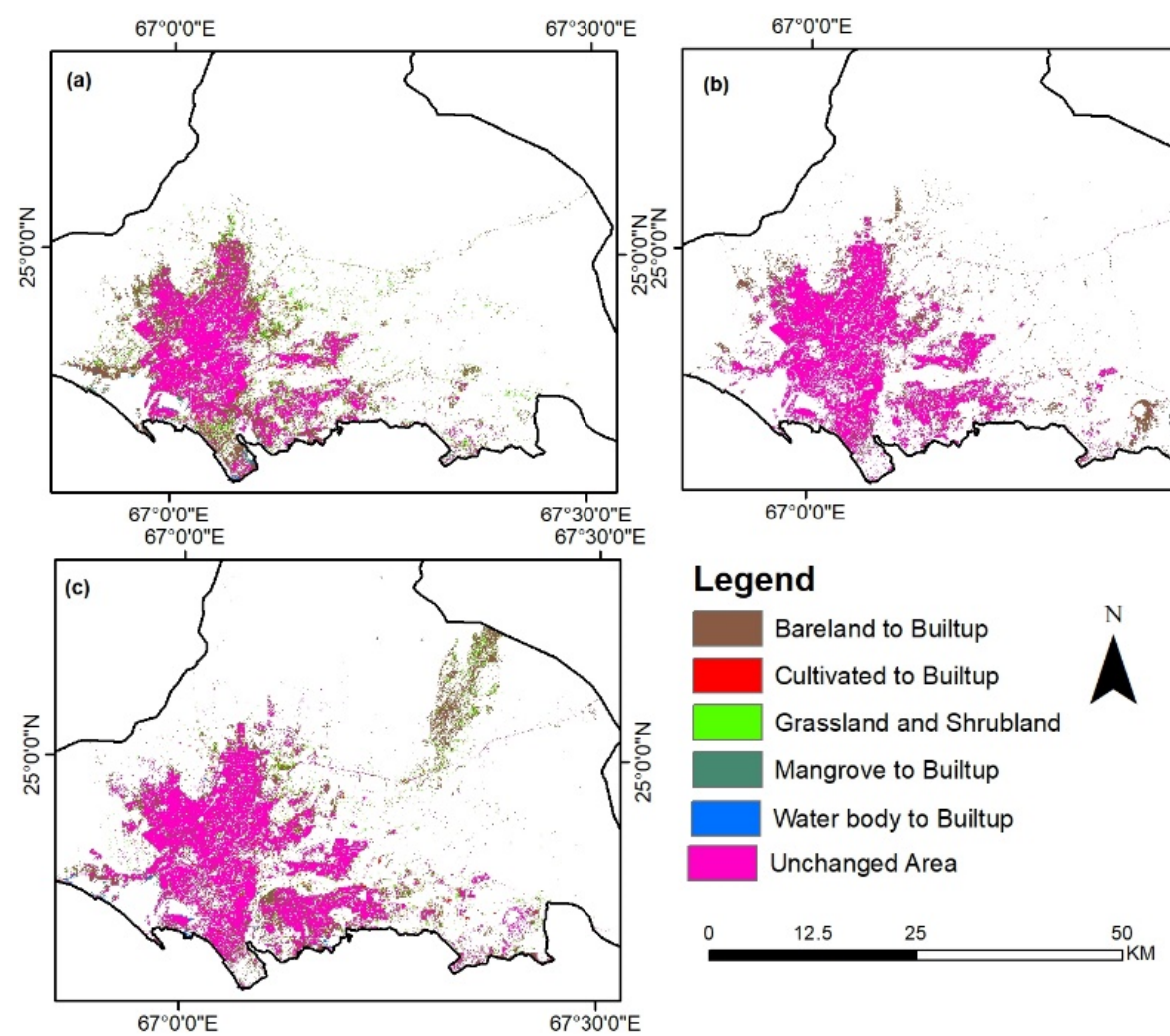

Figure 6. Spatial pattern of land transformation in Karachi during the periods of (a) 1990-2000, (b) 2000-2010, and (c) 2010-2020.

Table 5. Land transformation from other LULC classes to built-up area during the periods of 1990-2000, 2000-2010, and 2010-2020.

\begin{tabular}{|c|c|c|c|c|c|c|c|}
\hline \multirow{2}{*}{ Urban Land Transformation } & \multicolumn{3}{|c|}{ Area $\left(\mathrm{km}^{2}\right)$} & \multicolumn{4}{|c|}{ Change Rate (\%) } \\
\hline & 1990-2000 & 2000-2010 & 2010-2020 & 1990-2000 & 2000-2010 & 2010-2020 & 1990-2020 \\
\hline Bare land to Built-up & 114 & 68.7 & 134.2 & 4.28 & 2.44 & 5.38 & 117.71 \\
\hline Cultivated land to Built-up & 8.4 & 9.7 & 12.5 & 3.79 & 2.70 & 2.94 & 148.81 \\
\hline Grassland and Shrub land to Built-up & 42.6 & 13.1 & 30.2 & 37.96 & 8.22 & 20.35 & 70.89 \\
\hline Water to Built-up & 3 & 0.1 & 0.9 & 0.56 & 0.02 & 0.16 & 30.00 \\
\hline Mangroves to Built-up & 2.1 & 2 & 3.2 & 3.18 & 14.49 & 22.53 & 152.38 \\
\hline Expansion of Built-up Area & 170.1 & 93.6 & 181 & 714.70 & 201.29 & 335.18 & 106.40 \\
\hline
\end{tabular}

\subsection{Urban Landscape Change}

The urban sprawl matrix was used to create urban landscape maps in the study area. The area of urban primary core increased from 145.9 square kilometers in 1990 to 363.5 square kilometers in 2020 (Table 6). In 1990, changes in the area of the primary core were registered in the areas that comprise the CBD area, namely, the South, East, and Central districts, and later in 2020, the urban primary core expended further into the suburban districts of Karachi such as the Malir, West, and Kiamari districts (Figure 7). The area of the urban secondary core also changed from 25.9 sq.km 1990 to 22.3 sq.km in 2020 (Table 6). In 1990, the urban secondary core was observed only in the districts of Malir and Korangi, while later in 2020, the urban secondary core could be observed in other suburban areas of Karachi such as the districts of West and Kiamari. The observed urban secondary core areas in 1990 merged with the urban primary core in 2020 due to rapid expansion, and a new urban secondary core area emerged in the suburban areas of Karachi (Figure 7). 
Table 6. Urban landscape changes in Karachi during the periods of 1990-2000, 2000-2010, and 2010-2020.

\begin{tabular}{cccccccc}
\hline \multirow{2}{*}{ Urban Spatial Patterns } & \multicolumn{4}{c}{ Area (sq.km) } & \multicolumn{3}{c}{ Change Rate (\%) } \\
\cline { 2 - 7 } & $\mathbf{1 9 9 0}$ & $\mathbf{2 0 0 0}$ & $\mathbf{2 0 1 0}$ & $\mathbf{2 0 2 0}$ & $\mathbf{1 9 9 0 - 2 0 0 0}$ & $\mathbf{2 0 0 0 - 2 0 1 0}$ & $\mathbf{2 0 1 0 - 2 0 2 0}$ \\
\hline Urban Primary Core & 145.9 & 248 & 255 & 363.5 & 69.979 & 2.823 & 42.549 \\
Urban Secondary Core & 25.9 & 29.3 & 40 & 22.3 & 13.127 & 36.519 & -44.250 \\
Suburban Fringe & 25.2 & 22 & 22.09 & 35.8 & -12.698 & 0.409 & 62.064 \\
Scatter Settlement & 16.7 & 32.8 & 33.9 & 42.2 & 96.407 & 3.354 & 24.484 \\
Urban Open Space & 121.8 & 152.5 & 168.2 & 234.3 & 25.205 & 10.295 & 39.298 \\
Non-Urban Open Space & 3272 & 3131 & 3089 & 2911 & -4.309 & -1.341 & -5.762 \\
\hline
\end{tabular}
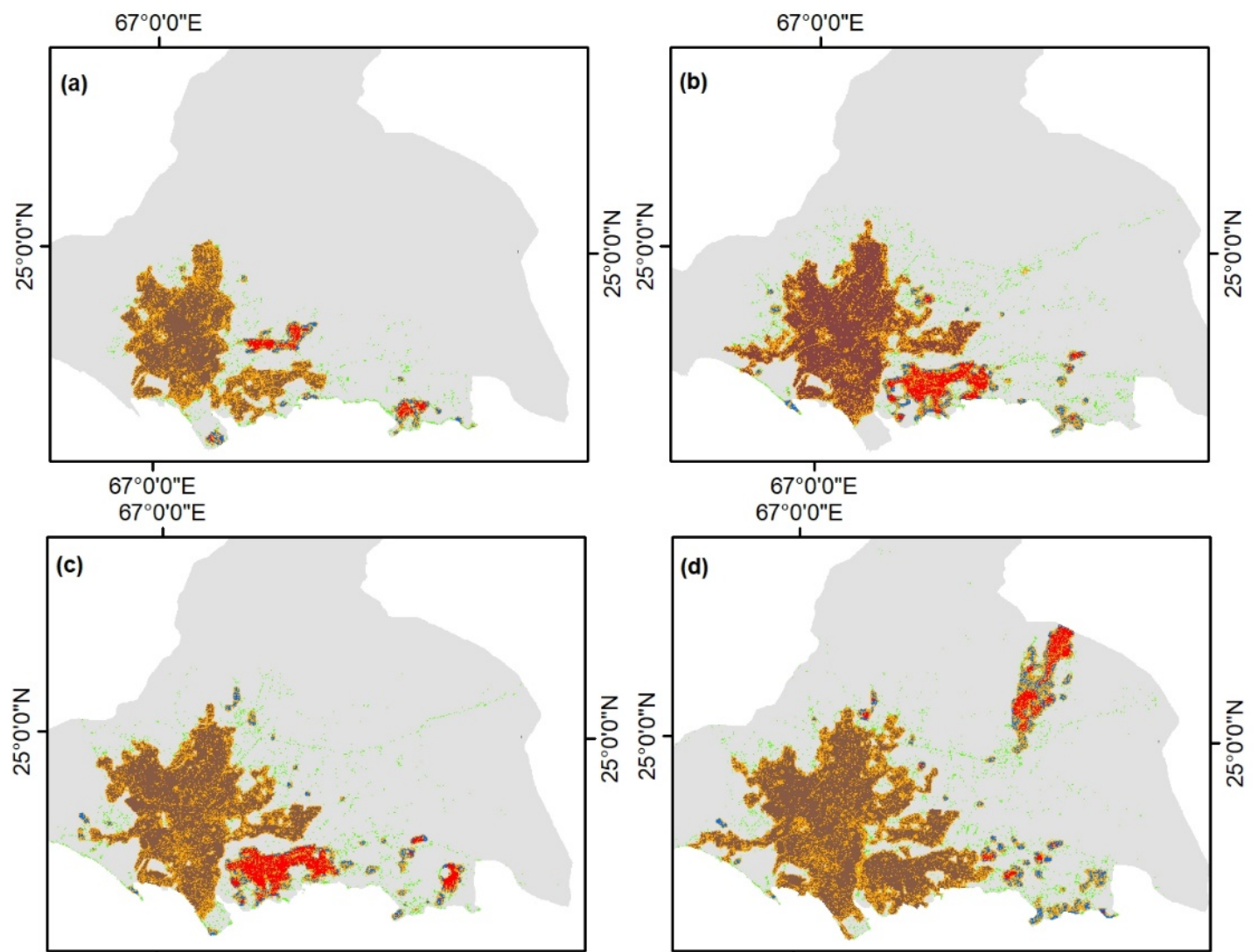

$67^{\circ} 0^{\prime} 0^{\prime E} \mathrm{E}$

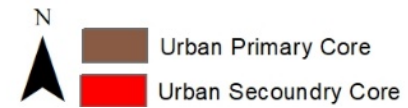

Suburban Fringe Scatter Settlement

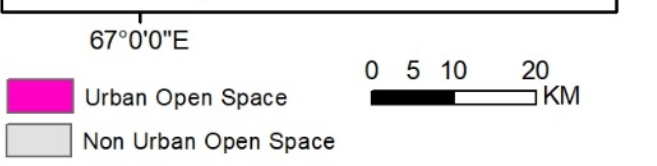

Figure 7. Urban landscape in Karachi in (a) 1990, (b) 2000, (c) 2010, and (d) 2020.

The area of the suburban fringe and scatter settlements showed a marginal increase (Table 6). The urban open space increased from 121.8 sq.km in 1990 to 243.3 ssq.km in 2020, which indicates an increase in green space under the urbanized area. Most of this increase was observed in the core of districts of East, Korangi, and Kiamari. A drastic decrease from 3272 sq.km in 1990 to 2911 sq. km in 2020 in the area of non-urban open space can also be observed.

The changes in each urban spatial pattern class within districts were analyzed (Table 7). Between 1990 and 2020, the Kiamari, East, West, and Korangi districts had rapid growth in the primary urban core. From 1990 to 2020, no urban secondary core was found in the district of Kiamari, Central, South, West, or East, while this was observed in the districts of Malir and Korangi. The urban secondary core in the Korangi district merged with the urban primary core in 2020. The newly developed Malir district experienced high urban secondary core growth due to the large number of commercial and residential 
developmental activities over the last two decades. The suburban fringe increased in the districts of Kiamari, West, East, and Malir, while the urban open space decreased within the Central and South districts. The decrease in open space in the CBD area might be attributed to the conversion of open space to residential and commercial lands.

Table 7. Urban landscape changes in different districts of Karachi (in percentage).

\begin{tabular}{|c|c|c|c|c|c|c|c|c|c|c|c|c|}
\hline \multirow{2}{*}{ District } & \multicolumn{3}{|c|}{ Primary Core } & \multicolumn{3}{|c|}{ Secondary Core } & \multicolumn{3}{|c|}{ Suburban Fringe } & \multicolumn{3}{|c|}{ Urban Open Space } \\
\hline & Phase 1 & Phase 2 & Phase 3 & Phase 1 & Phase 2 & Phase 3 & Phase 1 & Phase 2 & Phase 3 & Phase 1 & Phase 2 & Phase 3 \\
\hline Kiamari & 103.66 & 1.80 & 12.44 & 0.00 & 0.00 & 0.00 & 0.00 & 100.00 & 29.45 & 73.26 & -0.89 & 13.18 \\
\hline Central & 30.77 & -3.86 & 3.25 & 0.00 & 0.00 & 0.00 & 0.00 & 0.00 & 0.00 & -52.39 & 24.26 & -15.33 \\
\hline South & 44.86 & -5.02 & 15.44 & 0.00 & 0.00 & 0.00 & 0.00 & 0.00 & -100.00 & -12.23 & 60.64 & -7.21 \\
\hline West & 98.47 & 16.87 & 11.42 & 0.00 & 0.00 & 2100.00 & 0.00 & 0.00 & -9.18 & 33.73 & 37.25 & 33.09 \\
\hline East & 40.37 & 8.52 & 26.99 & 0.00 & -100.00 & 0.00 & 427.78 & 76.62 & 50.00 & 103.99 & 10.64 & 22.85 \\
\hline Korangi & 5728.57 & 7.78 & 251.51 & 100.10 & 25.38 & -100.00 & 46.63 & -114.47 & -100.00 & 1.23 & 12.82 & 3.69 \\
\hline Malir & 0 & 35.96 & 402.63 & -350.61 & 69.31 & 30.39 & 122.99 & 18.69 & 144.37 & 59.99 & 4.67 & 148.41 \\
\hline
\end{tabular}

\subsection{Transition Probability Matrix Analysis}

The transition probability matrix was generated for the time periods of 1990-2000, 2000-2010, and 2010-2020 to demonstrate the probability that each land cover type was projected to change (Table 8). The values on the diagonal of the matrix represent the possibility of a land cover type maintaining its original state, and the values on the nondiagonal represent the possibility of a land cover type converting to other types. From 1990 to 2000 , bare land was the most stable class with 0.77 probabilities, while the most dynamic class was cultivated land with transition probabilities of 0.32. From 2000 to 2010, water bodies were the most stable class with 0.67 probabilities, and grassland and shrub land were most dynamic with 0.20 probabilities. Similarly, from 2010 to 2020, mangroves were the most stable class with 0.76 probabilities, and cultivated land was the most dynamic class with 0.20 probabilities. The transition probability matrix from 2010 to 2020 was used to simulate the LULC map for Karachi city in 2030.

Table 8. Transition probability matrix of LULC classes in Karachi from 1990 to 2000, 2000 to 2010, and 2010 to 2020.

\begin{tabular}{|c|c|c|c|c|c|c|c|}
\hline Class & Time Period & Bare Land & Built-Up & $\begin{array}{l}\text { Cultivated } \\
\text { Land }\end{array}$ & $\begin{array}{l}\text { Grassland and } \\
\text { Shrub Land }\end{array}$ & Mangroves & $\begin{array}{l}\text { Water } \\
\text { Bodies }\end{array}$ \\
\hline \multirow{3}{*}{ Bare land } & Phase 1 & 0.77 & 0.10 & 0.40 & 0.06 & 0.00 & 0.00 \\
\hline & Phase 2 & 0.68 & 0.05 & 0.02 & 0.23 & 0.00 & 0.00 \\
\hline & Phase 3 & 0.61 & 0.05 & 0.01 & 0.32 & 0.00 & 0.00 \\
\hline \multirow{3}{*}{ Built-up } & Phase 1 & 0.14 & 0.70 & 0.05 & 0.08 & 0.00 & 0.00 \\
\hline & Phase 2 & 0.14 & 0.76 & 0.03 & 0.05 & 0.00 & 0.00 \\
\hline & Phase 3 & 0.03 & 0.85 & 0.03 & 0.03 & 0.03 & 0.03 \\
\hline \multirow{3}{*}{ Cultivated land } & Phase 1 & 0.39 & 0.88 & 0.32 & 0.18 & 0.00 & 0.00 \\
\hline & Phase 2 & 0.25 & 0.12 & 0.29 & 0.30 & 0.00 & 0.01 \\
\hline & Phase 3 & 0.27 & 0.05 & 0.20 & 0.46 & 0.00 & 0.00 \\
\hline \multirow{3}{*}{$\begin{array}{l}\text { Grassland and } \\
\text { shrub land }\end{array}$} & Phase 1 & 0.30 & 0.30 & 0.30 & 0.85 & 0.03 & 0.03 \\
\hline & Phase 2 & 0.54 & 0.14 & 0.10 & 0.20 & 0.00 & 0.00 \\
\hline & Phase 3 & 0.55 & 0.04 & 0.04 & 0.34 & 0.00 & 0.00 \\
\hline \multirow{3}{*}{ Mangroves } & Phase 1 & 0.09 & 0.14 & 0.02 & 0.01 & 0.41 & 0.30 \\
\hline & Phase 2 & 0.04 & 0.05 & 0.00 & 0.00 & 0.63 & 0.25 \\
\hline & Phase 3 & 0.07 & 0.04 & 0.00 & 0.02 & 0.76 & 0.08 \\
\hline \multirow{3}{*}{ Water bodies } & Phase 1 & 0.49 & 0.38 & 0.04 & 0.02 & 0.00 & 0.39 \\
\hline & Phase 2 & 0.12 & 0.12 & 0.00 & 0.00 & 0.05 & 0.67 \\
\hline & Phase 3 & 0.13 & 0.05 & 0.01 & 0.02 & 0.09 & 0.66 \\
\hline
\end{tabular}




\subsection{LULC Simulation Results}

The validation results showed strong agreement with the simulation map (Table 9). The kappa values indicate that the CA-Markov model used is suitable for simulating future LULC maps in the study area.

Table 9. Validation results of the CA-Markov model.

\begin{tabular}{cccccc}
\hline Year & \multicolumn{5}{c}{ Kappa Parameters } \\
\hline \multirow{2}{*}{2020} & K-location & K-no & K-location Strata & K-standard & Overall Kappa Value \\
& 0.91 & 0.91 & 0.91 & 0.87 & 0.87 \\
\hline
\end{tabular}

The simulated LULC maps for Karachi city in 2030 are shown in Figure 8, and the changes for each LULC type are tabulated in Table 10. The simulation results show that the bare land area will significantly decrease in 2030 due to its conversion to a built-up area. The districts of Malir, South, and Kiamari are seeing the most growth in terms of urban built-up area. The spatial pattern of the predicted LULC indicated that the city's new residents would settle in sub-urban fringes surrounding the urban cores. Living in these areas allows them to be closer to work and facilitates a more convenient commute. Grassland and shrub land covered about $838.42 \mathrm{~km}^{2}$ in 2020 and are expected to gradually increase to $999.06 \mathrm{~km}^{2}$ in 2030.

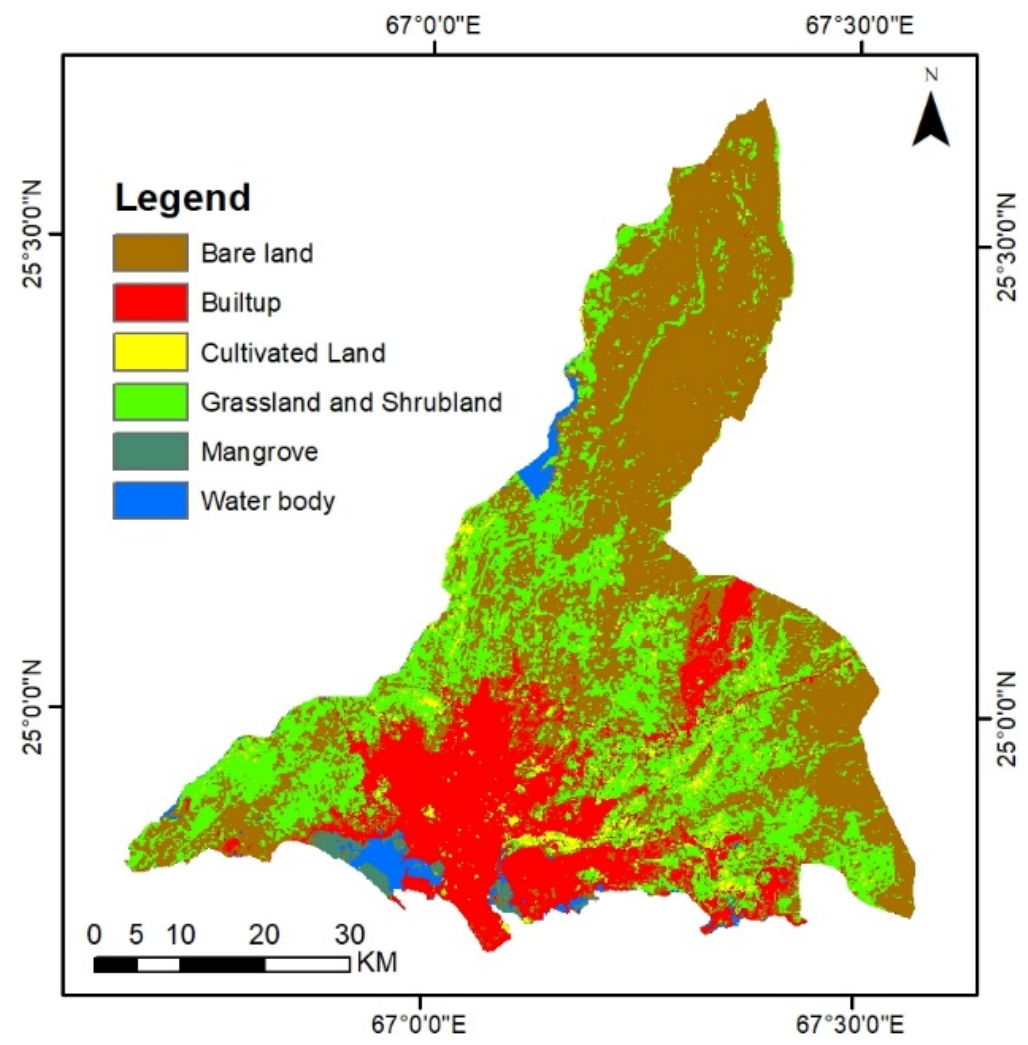

Figure 8. LULC prediction results for Karachi city in 2030. 
Table 10. Predicted LULC changes for Karachi city in 2030.

\begin{tabular}{ccccc}
\hline \multirow{2}{*}{ LULC Class } & \multicolumn{2}{c}{ Area (sq.km) } & \multicolumn{2}{c}{ Change } \\
\cline { 2 - 5 } & $\mathbf{2 0 2 0}$ & $\mathbf{2 0 3 0}$ & Sq.km & \% \\
\hline Bare land & 2031.74 & 1750.84 & -280.9 & $-86.17 \%$ \\
Built-up & 584.78 & 652.59 & 67.81 & $111.60 \%$ \\
Cultivated land & 78.39 & 99.46 & 21.07 & $126.88 \%$ \\
Grassland and & 838.42 & 999.06 & 160.64 & $119.16 \%$ \\
shrub land & 15.61 & 33.36 & 17.75 & $213.71 \%$ \\
Mangroves & 53.35 & 66.97 & 13.62 & $125.53 \%$ \\
Water bodies & & & & \\
\hline
\end{tabular}

Although the validation results showed that the CA-Markov model was a reliable method for simulating land use change, there are several limitations in our study. Socioeconomic factors are among the most important variables influencing land use changes. Our study was unable to investigate several potential socioeconomic causes of urban expansion due to a lack of spatial data. Moreover, more sophisticated models can be developed to simulate urban growth in different areas of the study area [55]. Landsat images with a resolution of $30 \mathrm{~m}$ were used to construct the land-use/cover maps for LULC modeling. High-resolution satellite data may be employed in the future to generate more detailed observations of specific agricultural and urban covers.

\section{Conclusions}

An urban sprawl matrix methodology was used in this study to analyze changes in urban spatial patterns in Karachi over three decadal epochs (1990-2000, 2000-2010, and 2010-2020). The utilization of the urban sprawl matrix provided an accurate and effective assessment of Karachi's urban expansion tendencies. Future land cover changes in the study area were predicted using a CA-Markov model for 2030. The results indicate that the built-up area had expanded in a considerably unpredictable manner, which was mainly at the expense of agricultural land. The increase in mangroves and grassland and shrub land demonstrated the effectiveness of afforestation programs in improving vegetation coverage in the study area. Fast urban development was recorded in districts including Malir, West, and Kiamari from 1990 to 2020. The primary urban core expanded from the core districts, namely, the Central, South, and Eastern districts, and a new urban secondary core was observed in Malir in 2020. The LULC simulation results for 2030 revealed a significant increase in urban built-up area of $111.6 \%$ compared with that in 2020 , mainly distributed in sub-urban fringes.

This study proved remote sensing and GIS techniques to be valuable tools in tracking and assessing changes in urban spatial patterns. The findings of the analysis can provide policy implications for future urban land transformation management and planning in order to achieve the Sustainable Development Goals. Future research could explore the forces that drive urban sprawl and examine how they interact with social, economic, and environmental repercussions in fast growing cities.

Author Contributions: Conceptualization, L.L. and F.C.; Methodology, M.F.B.; Software, M.F.B.; Validation, M.F.B.; Formal analysis, M.F.B.; Investigation, S.Q.; Resources, L.L.; Data curation, A.T.; Writing—original draft preparation, M.F.B.; Writing—review and editing, L.L., S.Q. and S.W.; Visualization, S.H.; Supervision, L.J.; Project administration, Q.L.; Funding acquisition, Q.L. All authors have read and agreed to the published version of the manuscript.

Funding: This research was funded by the National Key Research and Development Program of China (No. 2019YFD1100803).

Institutional Review Board Statement: Not applicable.

Informed Consent Statement: Not applicable. 
Data Availability Statement: The data presented in this study are available on request from the corresponding author.

Acknowledgments: The authors are grateful for the comments from anonymous reviewers and the editors.

Conflicts of Interest: The authors declare no conflict of interest.

\section{References}

1. United Nations. World Population Prospects 2019: Highlights; Department of Economic and Social Affairs, Population Division: New York, NY, USA, 2019; Available online: https:/ / population.un.org/wpp/Publications/Files/WPP2019_10KeyFindings.pdf (accessed on 10 March 2021).

2. Foley, J.A.; DeFries, R.; Asner, G.P.; Barford, C.; Bonan, G.; Carpenter, S.R.; Chapin, F.S.; Coe, M.T.; Daily, G.C.; Gibbs, H.K. Global consequences of land use. Science 2005, 309, 570-574. [CrossRef]

3. Grimm, N.B.; Faeth, S.H.; Golubiewski, N.E.; Redman, C.L.; Wu, J.; Bai, X.; Briggs, J.M. Global change and the ecology of cities. Science 2008, 319, 756-760. [CrossRef]

4. Thapa, R.B.; Murayama, Y. Urban growth modeling of Kathmandu metropolitan region, Nepal. Comput. Environ. Urban Syst. 2011, 35, 25-34. [CrossRef]

5. Pauleit, S.; Breuste, J.; Qureshi, S.; Sauerwein, M. Transformation of rural-urban cultural landscapes in Europe: Integrating approaches from ecological, socio-economic and planning perspectives. Landsc. Online 2010, 20, 1-10. [CrossRef]

6. Lu, L.; Weng, Q.; Guo, H.; Feng, S.; Li, Q. Assessment of urban environmental change using multi-source remote sensing time series (2000-2016): A comparative analysis in selected megacities in Eurasia. Sci. Total Environ. 2019, 684, 567-577. [CrossRef] [PubMed]

7. United Nations. Transforming Our World: The 2030 Agenda for Sustainable Development; United Nations, Department of Economic and Social Affairs: New York, NY, USA, 2015.

8. Inostroza, L.; Hamstead, Z.; Spyra, M.; Qureshi, S. Beyond urban-rural dichotomies: Measuring urbanisation degrees in central European landscapes using the technomass as an explicit indicator. Ecol. Indic. 2019, 96, 466-476. [CrossRef]

9. Hashem, N.; Balakrishnan, P. Change analysis of land use/land cover and modelling urban growth in Greater Doha, Qatar. Ann. GIS 2015, 21, 233-247. [CrossRef]

10. Lu, L.; Guo, H.; Corbane, C.; Li, Q. Urban sprawl in provincial capital cities in China: Evidence from multi-temporal urban land products using Landsat data. Sci. Bull. 2019, 64, 955-957. [CrossRef]

11. Li, X.; Liu, X.; Yu, L. A systematic sensitivity analysis of constrained cellular automata model for urban growth simulation based on different transition rules. Int. J. Geogr. Inf. Sci. 2014, 28, 1317-1335. [CrossRef]

12. Ke, X.; Qi, L.; Zeng, C. A partitioned and asynchronous cellular automata model for urban growth simulation. Int. J. Geogr. Inf. Sci. 2016, 30, 637-659. [CrossRef]

13. Mondal, B.; Das, D.N.; Bhatta, B. Integrating cellular automata and Markov techniques to generate urban development potential surface: A study on Kolkata agglomeration. Geocarto Int. 2017, 32, 401-419. [CrossRef]

14. Pijanowski, B.C.; Pithadia, S.; Shellito, B.A.; Alexandridis, K. Calibrating a neural network-based urban change model for two metropolitan areas of the Upper Midwest of the United States. Int. J. Geogr. Inf. Sci. 2005, 19, 197-215. [CrossRef]

15. Maithani, S. A neural network based urban growth model of an Indian city. J. Indian Soc. Remote Sens. 2009, 37, 363-376. [CrossRef]

16. Tang, J.; Wang, L.; Yao, Z. Spatio-temporal urban landscape change analysis using the Markov chain model and a modified genetic algorithm. Int. J. Remote Sens. 2007, 28, 3255-3271. [CrossRef]

17. Firozjaei, M.K.; Kiavarz, M.; Alavipanah, S.K.; Lakes, T.; Qureshi, S. Monitoring and forecasting heat island intensity through multi-temporal image analysis and cellular automata-Markov chain modelling: A case of Babol city, Iran. Ecol. Indic. 2018, 91, 155-170. [CrossRef]

18. Mondal, B.; Das, D.N.; Dolui, G. Modeling spatial variation of explanatory factors of urban expansion of Kolkata: A geographically weighted regression approach. Model. Earth Syst. Environ. 2015, 1, 1-13. [CrossRef]

19. Clarke, K.C.; Gaydos, L.J. Loose-coupling a cellular automaton model and GIS: Long-term urban growth prediction for San Francisco and Washington/Baltimore. Int. J. Geogr. Inf. Sci. 1998, 12, 699-714. [CrossRef]

20. Dadashpoor, H.; Nateghi, M. Simulating spatial pattern of urban growth using GIS-based SLEUTH model: A case study of eastern corridor of Tehran metropolitan region, Iran. Environ. Dev. Sustain. 2017, 19, 527-547. [CrossRef]

21. Bihamta, N.; Soffianian, A.; Fakheran, S.; Gholamalifard, M. Using the SLEUTH Urban Growth Model to Simulate Future Urban Expansion of the Isfahan Metropolitan Area, Iran. J. Indian Soc. Remote Sens. 2015, 43, 407-414. [CrossRef]

22. Park, S.; Jeon, S.; Choi, C. Mapping urban growth probability in South Korea: Comparison of frequency ratio, analytic hierarchy process, and logistic regression models and use of the environmental conservation value assessment. Landsc. Ecol. Eng. 2012, 8 , 17-31. [CrossRef]

23. Xian, G.; Crane, M.; McMahon, C. Quantifying multi-temporal urban development characteristics in Las Vegas from Landsat and ASTER data. Photogramm. Eng. Remote Sens. 2008, 74, 473-481. [CrossRef] 
24. Bununu, Y.A. Integration of Markov chain analysis and similarity-weighted instance-based machine learning algorithm (SimWeight) to simulate urban expansion. Int. J. Urban Sci. 2017, 21, 217-237. [CrossRef]

25. Angel, S.; Parent, J.; Civco, D. Urban sprawl metrics: An analysis of global urban expansion using GIS. In Proceedings of the ASPRS 2007 Annual Conference, Tampa, FL, USA, 7-11 May 2007.

26. Sharma, R.; Joshi, P.K. Monitoring Urban Landscape Dynamics Over Delhi (India) Using Remote Sensing (1998-2011) Inputs. J. Indian Soc. Remote Sens. 2013, 41, 641-650. [CrossRef]

27. Batty, M. Agents, Cells, and Cities: New Representational Models for Simulating Multiscale Urban Dynamics. Environ. Plan. A 2005, 37, 1373-1394. [CrossRef]

28. Jokar Arsanjani, J.; Helbich, M.; Kainz, W.; Darvishi Boloorani, A. Integration of logistic regression, Markov chain and cellular automata models to simulate urban expansion. Int. J. Appl. Earth Obs. Geoinf. 2013, 21, 265-275. [CrossRef]

29. Keshtkar, H.; Voigt, W. Potential impacts of climate and landscape fragmentation changes on plant distributions: Coupling multi-temporal satellite imagery with GIS-based cellular automata model. Ecol. Inform. 2016, 32, 145-155. [CrossRef]

30. Rimal, B.; Zhang, L.; Keshtkar, H.; Haack, B.; Rijal, S.; Zhang, P. Land Use/Land Cover Dynamics and Modeling of Urban Land Expansion by the Integration of Cellular Automata and Markov Chain. ISPRS Int. J. Geo-Inf. 2018, 7, 154. [CrossRef]

31. Akhtar, S.; Dhanani, M.R. Urban Sprawl in Karachi. Glob. Adv. Res. J. Geogr. Reg. Plan. 2013, 2, 160-171.

32. Schetke, S.; Qureshi, S.; Lautenbach, S.; Kabisch, N. What determines the use of urban green spaces in highly urbanized areas?-Examples from two fast growing Asian cities. Urban For. Urban Green. 2016, 16, 150-159. [CrossRef]

33. Qureshi, S. The fast growing megacity Karachi as a frontier of environmental challenges: Urbanization and contemporary urbanism issues. J. Geogr. Reg. Plan. 2010, 3, 306-321.

34. Hamza, S.; Khan, I.; Lu, L.; Liu, H.; Burke, F.; Nawaz-ul-Huda, S.; Baqa, M.F.; Tariq, A. The Relationship between Neighborhood Characteristics and Homicide in Karachi, Pakistan. Sustainability 2021, 13, 5520. [CrossRef]

35. D'Acci, L. A new type of cities for liveable futures. Isobenefit Urbanism morphogenesis. J. Environ. Manag. 2019, 246, 128-140. [CrossRef] [PubMed]

36. Shaikh, A.; Gotoh, K. A Satellite Remote Sensing Evaluation of Urban Land Cover Changes and Its Associated Impacts on Water Resources in Karachi, Pakistan. J. Jpn. Soc. Photogramm. Remote Sens. 2006, 45, 41-55. [CrossRef]

37. Mahboob, M.A.; Atif, I.; Iqbal, J. Remote Sensing and GIS Applications for Assessment of Urban Sprawl in Karachi, Pakistan. Sci. Technol. Dev. 2015, 34, 179-188. [CrossRef]

38. City District Government Karachi. Karachi Strategic Development Plan 2020; CDGK (City District Government Karachi): Karachi, Pakistan, 2007; Available online: https:/ / urckarachi.org/2020/07/19/karachi-strategic-development-plan-2020/ (accessed on 15 January 2021).

39. Government of Pakistan. Pakistan Bureau of Statistics; 2017. Available online: https://www.pbs.gov.pk/ (accessed on 15 December 2020).

40. Ahmed, Q.I.; Lu, H.; Ye, S. Urban transportation and equity: A case study of Beijing and Karachi. Transp. Res. Part A Policy Pract. 2008, 42, 125-139. [CrossRef]

41. Government of Pakistan. Pakistan Economic Survey; 2017-2018. Available online: http://www.finance.gov.pk/survey_1718.html (accessed on 15 December 2020).

42. World Bank. Transforming Karachi into a Livable and Competitive Megacity: A City Diagnostic and Transformation Strategy; The World Bank: Washington, DC, USA, 2018; Available online: https:/ /openknowledge.worldbank.org/bitstream/handle/10986/29376/ 211211ov.pdf? sequence=8\&isAllowed=y (accessed on 15 January 2021).

43. Haq, U. The Rise of Karachi as a Mega-City: Issues and Challenges. Human Development Centre. Available online: http: // www.mhhdc.org (accessed on 9 January 2021).

44. Hasan, A.; Ahmed, N.; Raza, M.; Sadiq, A.; Ahmed, S.; Sarwar, M.B. Land Ownership, Control and Contestation in Karachi and Implications for Low-Income Housing; Human Settlements Group, International Institute for Environment and Development: London, UK, 2013.

45. Lu, L.; Kuenzer, C.; Wang, C.; Guo, H.; Li, Q. Evaluation of Three MODIS-Derived Vegetation Index Time Series for Dryland Vegetation Dynamics Monitoring. Remote Sens. 2015, 7, 7597-7614. [CrossRef]

46. Lu, L.; Weng, Q.; Xiao, D.; Guo, H.; Li, Q.; Hui, W. Spatiotemporal Variation of Surface Urban Heat Islands in Relation to Land Cover Composition and Configuration: A Multi-Scale Case Study of Xi'an, China. Remote Sens. 2020, 12, 2713. [CrossRef]

47. Parent, J.; Civco, D.; Angel, S. Urban Growth Analysis: Calculating Metrics to Quantify Urban Sprawl; University of Connecticut: Storrs, CT, USA, 2008; Available online: https:/ / proceedings.esri.com/library/userconf/proc08/papers/papers/pap_1692.pdf (accessed on 9 March 2021).

48. Mas, J.-F.; Kolb, M.; Paegelow, M.; Olmedo, M.T.C.; Houet, T. Inductive pattern-based land use/cover change models: A comparison of four software packages. Environ. Model. Softw. 2014, 51, 94-111. [CrossRef]

49. Kumar, S.; Radhakrishnan, N.; Mathew, S. Land use change modelling using a Markov model and remote sensing. Geomat. Nat. Hazards Risk 2014, 5, 145-156. [CrossRef]

50. Guan, D.; Li, H.; Inohae, T.; Su, W.; Nagaie, T.; Hokao, K. Modeling urban land use change by the integration of cellular automaton and Markov model. Ecol. Model. 2011, 222, 3761-3772. [CrossRef]

51. Tariq, A.; Shu, H. CA-Markov Chain Analysis of Seasonal Land Surface Temperature and Land Use Land Cover Change Using Optical Multi-Temporal Satellite Data of Faisalabad, Pakistan. Remote Sens. 2020, 12, 3402. [CrossRef] 
52. Lillesand, T.; Kiefer, R.W.; Chipman, J. Remote Sensing and Image Interpretation; John Wiley \& Sons: Hoboken, NJ, USA, 2015.

53. Shawul, A.A.; Chakma, S. Spatiotemporal detection of land use/land cover change in the large basin using integrated approaches of remote sensing and GIS in the Upper Awash basin, Ethiopia. Environ. Earth Sci. 2019, 78, 1-13. [CrossRef]

54. Mahar, G.A.; Hussain, B.; Wagan, R.A.; Hussain, A.T.; Khan, S.H. Remote sensing (RS) monitoring of mangroves plantation against the guinness world record (GWR) of maximum plantation in indus delta. Pak. J. Bot. 2020, 52, 1497-1503. [CrossRef]

55. Liu, Y.; He, Q.; Tan, R.; Liu, Y.; Yin, C. Modeling different urban growth patterns based on the evolution of urban form: A case study from Huangpi, Central China. Appl. Geogr. 2016, 66, 109-118. [CrossRef] 